\title{
BROOMRAPE AND OTHER WEED CONTROL IN CARROT (DAUCUS CAROTA L.)
}

\author{
*GHALWASH, A. M., I. E. SOLIMAN* and AZZA E. KHAFFAGY* \\ * Weed Research Central Laboratory, ARC, Giza, Egypt.
}

(Manuscript received 13 January 2014)

\begin{abstract}
Four field experiments were conducted at Sakha Agricultural Research Station, Kafer El-Sheikh Governorate in the two successive winter seasons $2011 / 12$ and $2012 / 13$, to study the efficacy of some weed control treatments on broomrape and annual weeds control, as well as, on carrot yield productivity and its quality. The first study, used the herbicides glyphosate twice, imazapic twice, as postemergence herbicides and hand pulling twice to broomrape control as a parasite weed. The second study, used the herbicides pendimthalin, butralin , oxyfluorfen, metribuzin as per-emergence herbicides and hand weeding twice for controlling annual weeds. The results indicated that herbicide: imazapic twice, gave the best broomrape control and the highest increase in carrot roots yield and its quality, followed by glyphosate, and hand pulling twice of broomrape spikes, respectively. The herbicides imazapic and glyphosate decreased number of broomrape spikes/ $\mathrm{m}^{2}$, weight of broomrape spikes $/ \mathrm{m}^{2}$, spikes length and number of capsules/ spike. The previous pre-herbicides exceeded in a great extent the unweeded treatment in controlling annual broad-leaved weeds and annual grassy weeds. The maximum reduction values of dry weight of broad-leaved, grassy and total annual weeds were obtained by using oxyfluorfen, pendimethalin, metribuzin, butralin and hand weeding twice in two seasons, respectively, compared with the control treatment. The herbicides oxyfluorfen, imazapic, pendimethalin, metribuzin, glyphosate and butralin gave the highest increases in yield and its components in both seasons, compared with the control treatment. All tested herbicides gave the highest significant increase in the quality characters in carrot roots, followed by hand pulling of broomrape or hand weeding of the annual weeds. Also, the highest net return was obtained by herbicides used and hand weeding twice, Thus, these herbicides treatments can replace hand weeding for the control of weeds and broomrape in carrot crop.
\end{abstract}

Key words: Orobanche, Carrot, Broomrape, Weed Control.

\section{INTRODCTION}

Carrot has a few herbicides that could be used as per- or post- emergence in Egypt. The use of herbicides in carrot fields plays an important role in improving the growth of carrot plants and consequently increase the productivity of land unit 
area and lowering the cost of production as compared to hand weeding. Carl et. al. (2000) reported that weed control options are very limited in carrots. Carrots don't compete well against weeds, and herbicides are important tools for producing highyield and high -quality carrots. Boydston et. al. (2003) reported that carrot is a small seeded, initially slow growing crop that can suffer severe yield losses from weed competition. Dittmar and Stall (2012) indicated that weeds reduce carrot yields by reducing the size of carrot roots though direct competition for nutrients, space and water. Weeds also deform carrot roots, making them unmarketable. Furthermore, weeds which grow late in the season may also cause severe harvesting problems. Karaliauskaite et. al. (2008) stated that the efficiency of metribuzin herbicide was higher when it was sprayed single $(0.5 \mathrm{l} / \mathrm{ha})$ at carrot $1-2$ leaves stage and the amount of weeds was reduced by $84 \%$. On the other hand, Jacobsohn et. al. (1980) mentioned that (Orobanche aegyptica L.) is a phanerogamic holoparasite without chlorophyll that may cause severe damage to many broad-leaved vegetables and field crops. Carrot plants without control become stunted due to heavy parasitization with broomrape and they were completely destroyed by the end of the season. Aviv et. al. (2002) stated that parasitic (Orobanche spp.) are majer constraints to vegetable crop production in the Mediterranean basin to Eastern Europe. Schaffer et. al. (1991) proved that (Orobanche aegyptica Pers) and ( $O$. crenata, Forsk) decreased the total sugar control similarly in carrot roots. Sucrose was the primary sugar in non infected roots and its level was greatly reduced in infected roots. So, broomrape infection can reduce carrot roots quality even when the visual appearance of the roots are not affected. Jacobsohn and kelman (1982) reported that broomrape (Orobanche spp) control and high yields of carrots were obtained by spray application of 1.0 or $1.5 \mathrm{~kg}$ glyphosate /ha in January with 1-3 additional sprays applied at equal intervals (15 days) up to application. Nandula et. al. (2002) mentioned that the changes in the composition of both free and bound amine acids in carrot are associated with broomrape parasitism.

Farag et. al. (1994) stated that weeds associated carrot plants caused a 57$67 \%$ reduction in carrot root yield. In weed control plots, carrot root yield, root/shoot ratio and total carotenoids were increased, while, total soluble solids and dry matter content were decreased. Some selective herbicides gave the hope of solving this problem. Further, Gesagared herbicide gave the highest total sugar content and hand weeding twice can be used for weed control and improvement of yield and quality in carrots crops. 
So, the present investigation was conducted to study the effect of some weed control treatments on broomrape and annual weeds control, as well as to study their effects on growth, and quality characters of carrot roots.

\section{MATERIALS AND METHODS}

Four field experiments were carried out at Sakha Agricultural Research Station, during the two $2011 / 12$ and 2012/13 successive winter seasons, to study the effectiveness of some weed control treatments on controlling broomrape (Orobanche crenata, Forsk.) and some annual weeds in carrot (Daucus carota L.), as well as carrot yield and it's components. Carrot cultivar, Chantenay Red cored, was sown on the $5^{\text {th }}$ and $10^{\text {th }}$ of October in the first and second seasons, respectively, and yield uprooted harvested at the $5^{\text {th }}$ and $10^{\text {th }}$ of February) 2012. The soils of the four experiments were clay textured.

Table 1. Soil mechanical analysis of the experimental sites.

\begin{tabular}{|c|c|c|c|c|c|c|}
\hline \multirow{2}{*}{ oil depth (cm) } & \multicolumn{3}{|c|}{ Particle size distribution \% } & \multirow{2}{*}{ Texture } & $\begin{array}{c}\text { Bulk density, } \\
\left(\mathrm{g} / \mathrm{cm}^{3}\right)\end{array}$ & eld capacity \% \\
\cline { 2 - 4 } & Sand & Silt & Clay \% & Clay & $1-1$ & 44.80 \\
\hline $0-15$ & 15.6 & 19.35 & 64.97 & Clay & $1-21$ & 41.45 \\
\hline $15-30$ & 20.4 & 14.3 & 65.30 & clay & $1-28$ & 39.27 \\
\hline $30-45$ & 17.09 & 17.0 & 65.01 & & \\
\hline
\end{tabular}

The experiments were carried out in a randomized complete black design, with four replicates. plot area was $10.5 \mathrm{~m}^{2}$. The present study divided into two parts as follows:-

\section{Part I-Effect of Orobanche control treatments on broomrape.}

In these experiments, the plots were naturally infested with broomrape seeds. Other weeds were removed by hand weeding. Each experiment consisted of four Orobanche control treatments as follows:

1- Glyphosate [( $\mathrm{N}$ - phosphonomethyl ) glycine] , known commercially as Round up $48 \%$ WSC, was applied twice with equal rate at $36.0 \mathrm{~g}$ a.i./fed. after 50 days from sowing, followed with 21 days interval.

2- Imazapic [( \pm )-2-[4,5-dihydro-4-methyl-4-(1-methylethyl)-5-oxo-1H-imidazol-2yl]-5-methyl-3-pyridinecarboxylic acid], known commercially as Oroban $10 \%$ EC, was applied twice and equal rate at $20 \mathrm{~g}$ a.i./fed. after 50 days from sowing , followed with 21 days interval.

3- Hand pulling (twice), beginning after 15 days from emergence broomrape spikes with 21 days intervals between them.

4- Untreated check. 


\section{Part II- Effect of weed control treatments on annuls weeds.}

Two experiments were carried out, each experiment consisted of six weed control treatments, as follows:-

1. Butralin [4-(1,1-dimethylethyl)- $N$-(1-methylpropyl)-2,6-dinitrobenzenamine], known commercially as Amex 48\% EC was applied once with a rate of 96.0 $\mathrm{g}$ a.i./fed., surface application after sowing and before irrigation.

2. Oxyfluorfen [2-chloro-1-(3-ethoxy-4-nitrophenoxy)-4 (trifluoromethyl) benzene], known commercially as Goel 24\% EC was applied once and equal rate at $120 \mathrm{~g}$ a.i./fed., after 21 days from sowing.

3. Metribuzin [4-amino-6-tert-butyl-4,5-dihydro-3-methylthio-1,2,4-triazin-5one,4-amino-6-tert-butyl-3-methylthio-1,2,4-triazin-5(4H)-one], known commercially as Sencor $70 \%$ WP was applied twice and equal rate of $36.0 \mathrm{~g}$ a.i./fed., after 21 days from sowing, followed with 21 days interval.

4. Pendimethalin [N-(1-ethylpropyl)-3,4-dimethyl-2,6-dinitrobenzenamine], known commercially as Stomp 50\% EC was applied once and equal rate of $850 \mathrm{~g}$ a.i./fed., surface application after sowing and before irrigation.

5. Hand weeding (twice) was carried out at 18 and 32 days from sowing.

6. untreated check.

Herbicides in both field experiments were sprayed by knapsack sprayer CP3 in water volume of 200 liters per faddan. The preceding summer crop in the two seasons was maize (Zea mays L.). Plot area was $10.5 \mathrm{~m}^{2}$ (3.5m length and $3.0 \mathrm{~m}$ width). Each plot contained four rows. During the two seasons, calcium super phosphate $(15.5 \%)$ at a rate of $100 \mathrm{~kg} / \mathrm{fed}$ was added before planting and nitrate $(33.5 \% \mathrm{~N})$ at a rate of $100 \mathrm{~kg} / \mathrm{fed}$.) was added before planting. Other cultural practices for carrot production were applied as recommended. The collected data were as follows:

\section{In experiments of controlling broomrape.}

\section{1. broomrape characteristics.}

Prior to carrot harvesting, number of broomrape spike $/ \mathrm{m}^{2}$, weight broomrape $/ \mathrm{m}^{2}$, spike length $(\mathrm{cm})$ and number of capsules/ spike were estimated.

\section{In experiments for controlling the annual weeds.}

\section{On susceptibility rating of weeds.}

The susceptibility of weeds to herbicides was measured after 28 days from application of the herbicides by the reduction percentage of the dry weight of each species compared to the un-weeded check according to Frans and Talbert (1977) as follows:

- Susceptible (S) $=>90 \%$ reduction.

- Moderately susceptible (MS) $=80-89 \%$ reduction. 
- Moderately tolerant $\quad(M T)=60-79 \%$ reduction.

- Tolerant $(T)=<60 \%$ reduction.

\section{2- On dry weight of annual weeds.}

Annual weeds were hand weeding after 45 and 75 days from sowing and classified into three categories (broad-leaved, grassy and total weeds). The dry weight of weeds was determined in $\mathrm{g} / \mathrm{m}^{2}$, after drying in a forced draft oven at $70 \mathrm{C}^{\circ}$ for 48 hours.

\section{- Carrot yield and its components.}

At harvest time, samples of ten carrot plants were collected randomly from the central rows of each plot to assess the following criteria: root length $(\mathrm{cm})$, root diameter $(\mathrm{cm})$, number of roots $/ \mathrm{m}^{2}$. Carrot plants were harvested from each plot, carrot root yield per plot was weighed and estimated as ton per feddan (fed).

\section{Carrot quality characters.}

At harvest, the following data were recorded from ten carrot plants from each plot:

a) Total soluble solids \% (T.S.S) in carrot roots was measured by a Carl Zeiss handefra- ctometer.

b) Dry matter \% in roots.

c) Total sugar was determined in carrot roots on fresh weight basis, according to the methods outlined by Poschenok (1976).

d) Total carotenoid content ( $\mathrm{mg} / 100 \mathrm{gm}$ fresh weight) was determined according the method described by Ranganna(1977).

\section{Economic evaluation.}

Net return was calculated by expressing the cost and yield of the unit area in monetary. The retail price used in computing cash returns was L.E 5 (Egyptian pounds) for carrot/kg for both seasons. The costs were negated from the overall cash returns as the resulted cash was considered to be the net return.

\section{Statistical analysis.}

The obtained data were subjected to proper statistical analysis of variance, according to Snedecor and Cochran (1980) and the least significant differences (LSD) at the $5 \%$ level of probability were calculated. 


\section{RESULTS AND DISCUSSION}

\section{Part I- Effect of broomrape control treatments.}

\section{- On broomrape.}

Data presented in Table (2) show that the nature broomrape infestation in untreated check treatment was 20.02 and 22.93 number of spikes $/ \mathrm{m}^{2}$ or 113.35 and $106.55 \mathrm{~g} / \mathrm{m}^{2}$ in both seasons, respectively. Imazapic applied twice at $20 \mathrm{~g}$ a.i./fed (post- emergence) and hand pulling twice gave approximately equal reduction effect, where reduction in number of broomrape spikes $/ \mathrm{m}^{2}$, dry weight of spikes $\left(\mathrm{g} / \mathrm{m}^{2}\right)$, spike length (cm) and number of capsules / spike was (83.1, 86.6, 80.9 and $80.5 \%$ ) $(80.1,85.1,75.5$ and $79.2 \%)$ in the first season, and (81.6, 82.1, 80.3 and $81.1 \%)$ and $(78.9,81.7,77.3$ and $76.5 \%)$ in the second season, respectively, compared to untreated check. While, glyphosate applied twice at $36.0 \mathrm{~g}$ a.i./fed as postemergence herbicide gave the following reduction percentage in the previous respective characteristics $(75.7,82.7,61.4$ and 70.7\%), in first season and (75.0, $79.1,70.6$ and $71.1 \%$ ), in the second season, respectively, compared to untreated check. The obtained results were in agreement with those findings of Hassanein and Kholosy (1997) and Ghalwash et. al. (2008) who reported that the action of imazapic and glyphosate on broomrape is attributable to its selective accumulation in the young parasite plant up to four times as high as that in faba bean host root, three days after spraying.

Table 2. Effect of broomrape control treatments on broomrape infestation in 2011/12 and 2012/13 winter seasons.

\begin{tabular}{|c|c|c|c|c|}
\hline \multirow{2}{*}{$\begin{array}{c}\text { Broomrape control } \\
\text { treatments }\end{array}$} & \multicolumn{4}{|c|}{$2011 / 12$ season } \\
\hline & $\begin{array}{l}\text { Number of } \\
\text { spikes } / \mathrm{m}^{2}\end{array}$ & $\begin{array}{l}\text { Dry weight of } \\
\text { spikes } \mathrm{g} / \mathrm{m}^{2}\end{array}$ & $\begin{array}{l}\text { Spike length } \\
(\mathrm{cm})\end{array}$ & $\begin{array}{c}\text { Number of } \\
\text { capsules/ spike }\end{array}$ \\
\hline Glyphosate (36.0 g a.i./fed) & 4.86 & 19.62 & 15.73 & 6.93 \\
\hline Imazapic (20.0 g a.i./fed) & 3.38 & 15.23 & 7.78 & 4.61 \\
\hline Hand pulling twice & 3.98 & 16.93 & 9.98 & 4.92 \\
\hline Untreated check & 20.02 & 113.35 & 40.79 & 23.68 \\
\hline \multirow[t]{2}{*}{ LSD at $5 \%$} & 1.15 & 3.43 & 2.08 & 1.28 \\
\hline & \multicolumn{4}{|c|}{$2012 / 13$ season } \\
\hline Glyphosate (36.0 g a.i./fed) & 5.72 & 22.32 & 14.53 & 7.76 \\
\hline Imazapic (20.0 g a.i./fed) & 4.23 & 19.05 & 9.73 & 5.08 \\
\hline Hand pulling twice & 4.83 & 19.47 & 11.24 & 6.29 \\
\hline Untreated check & 22.93 & 106.55 & 49.42 & 26.82 \\
\hline LSD at $5 \%$ & 1.13 & 2.26 & 1.79 & 1.39 \\
\hline
\end{tabular}

\section{- On carrot yield components and quality.}

Data in Table (3) indicated that imazapic at $20 \mathrm{~g}$ a.i./fed and glyphosate at $36 \mathrm{~g}$ a.i./fed. gave the highest significant increase percentage in weight of carrot 
roots/fed by (52.8 and $52.19 \%$ ), respectively compared to untreated check in first season and (50.27 and 49.21\%), respectively in second season. While, hand pulling twice gave an increases percentage by (31.43 and 37.64\%), respectively in 2011/12 and 2012/13 seasons, respectively. Similar results were obtained in case of carrot components and its quality in both seasons. In the first season, imazapic at $20 \mathrm{~g}$ a.i. /fed and glyphosate at $36 \mathrm{~g}$ a.i. /fed gave the highest values of root length (16.7 and $15.6 \mathrm{~cm})$, root diameter $(3.7$ and $3.1 \mathrm{~cm})$, number of roots $/ \mathrm{m}^{2}$ (175.7 and 158.4), TSS by ( 9.9 and $8.9 \%)$ total carotene $(81.7$ and $76.1 \mathrm{mg})$, and total sugar (10.2 and $9.5 \mathrm{~g})$, respectively. The obtained results in the first season confirmed to a great extent those observed in second season with minor differences. In the second season, imazapic at $20 \mathrm{~g}$ a.i. and glyphosate at $36 \mathrm{~g}$ a.i. /fed. gave the highest values of root length $(15.96$ and $14.0 \mathrm{~cm})$, root diameter $(3.85$ and $3.3 \mathrm{~cm})$, number of roots $/ \mathrm{m}^{2}$ (152 and 148), TSS (8.7 and $9.4 \%)$, total carotene $(86.7$ and79.5 mg) and total sugar (10.0 and $9.2 \mathrm{~g})$, respectively.

Table 3. Effect of bromrape control treatments on yield components and its quality at harvest in carrot during 2011/12 and 2012/13 winter seasons.

\begin{tabular}{|c|c|c|c|c|c|c|c|c|}
\hline \multirow[b]{2}{*}{ Bromrape control treatments } & \multicolumn{8}{|c|}{ 2011/12 season } \\
\hline & $\begin{array}{l}\text { Root } \\
\text { length } \\
(\mathrm{cm})\end{array}$ & $\begin{array}{c}\text { Root } \\
\text { diameter } \\
(\mathrm{cm})\end{array}$ & $\begin{array}{c}\text { Number of } \\
\text { root } / \mathrm{m}^{2}\end{array}$ & $\begin{array}{l}\text { Weight of } \\
\text { root } \\
\text { (ton/fed) }\end{array}$ & $\begin{array}{c}\text { TSS } \\
\%\end{array}$ & $\begin{array}{c}\text { Dry } \\
\text { matte } \\
\text { r \% }\end{array}$ & $\begin{array}{c}\text { Total } \\
\text { caroten } \\
\text { oides } \\
(\mathrm{M} / \mathrm{g})\end{array}$ & $\begin{array}{c}\text { Total } \\
\text { sugar } \\
\text { g/ } \\
\text { (F.w) }\end{array}$ \\
\hline Glyphosate (36.0 g, a.i./fed) & 15.60 & 3.10 & 158.4 & 11.86 & $8 . .90$ & 10.80 & 76.10 & 9.50 \\
\hline Imazapic (20.0 g, a.i./fed) & 16.70 & 3.70 & 175.7 & 12.02 & $9 . .90$ & 11.5 & 81.70 & 10.20 \\
\hline Hand pulling twice & 11.20 & 2.01 & 135.7 & $8 . .27$ & $7 . .90$ & 7.80 & 59.70 & 8.60 \\
\hline Untreated check & 8.30 & $1 . .51$ & 95.7 & 5.67 & $5 . .50$ & 5.70 & 42.30 & $5 . .90$ \\
\hline \multirow[t]{2}{*}{ LSD at $5 \%$} & $1 . .29$ & 0.851 & 31.5 & 2.31 & $1 . .97$ & $2 . .50$ & 12.40 & 1.61 \\
\hline & \multicolumn{8}{|c|}{$2012 / 13$ season } \\
\hline Glyphosate (36.0 g, a.i./fed) & 14.00 & 3.30 & 148.2 & 10.83 & 9.40 & 11.80 & 79.50 & 9.20 \\
\hline Imazapic (20.0 g, a.i./fed) & 15.46 & 3.85 & 152.7 & 11.06 & 8.70 & 12.20 & 86.70 & 10.00 \\
\hline Hand pulling twice & 10.10 & 2.12 & 126.5 & 8.82 & $7 . .51$ & 8.10 & 60.10 & $8 . .20$ \\
\hline Untreated check & $7 . .30$ & 1.60 & 88.3 & 5.50 & 5.70 & 5.90 & 39.30 & $5 . .50$ \\
\hline LSD at $5 \%$ & $1 . .53$ & 0.821 & 27.90 & 3.31 & 2.03 & $2 . .97$ & 15.9 & 1.67 \\
\hline
\end{tabular}

\section{- Economic evaluation (net return):}

Data in Table (4) showed that the net profit of carrot roots yield by weed control treatments in the first season could be arranged in descending order as follows: 10678 LE by imazapic at $20 \mathrm{~g}$ a.i./fed., $10554 \mathrm{LE}$ by glyphosate at $36 \mathrm{~g}$ a.i. /fed, and 7979 LE by hand pulling twice, compared to untreated check 5850 LE. In the second season the same trend approximately for net profit was confirmed to those observed in first season. The net profit of carrot roots yield by the following treatments in a descending order was 9814 LE by imazapic at $20 \mathrm{~g}$ a.i./fed, 9627 LE by glyphosate at $36 \mathrm{~g}$ a.i. /fed, and $8231 \mathrm{LE}$ by hand weeding twice, compared to untreated check 5373 LE. These results are in agreement with those reported by 
(Sanjeev et. al. 2003, Dillared et. al. 2004 and Dixit et. al. 2005) who found that use of the herbicide pendimethalin and hand hoeing gave the highest yield and net return. This result my be due to the increase in leaf area /plant, dry weight of leaves $\%$ and gross head weight due to these treatments.

Table 4. Cost of weed control treatments, total root yield ton/fed and net return of carrot yield (L.E./fed) as affected by weed control treatments during 2011/12and 2012/13 seasons.

\begin{tabular}{|c|c|c|c|c|c|c|}
\hline \multirow[b]{2}{*}{ Weed control treatments } & \multicolumn{3}{|c|}{$2011 / 12$} & \multicolumn{3}{|c|}{$2012 / 13$} \\
\hline & $\begin{array}{l}\text { Cost of } \\
\text { W.C.T. } \\
\text { (L.E /fed.) }\end{array}$ & $\begin{array}{l}\text { T. root } \\
\text { yield } \\
\text { ton/fed. }\end{array}$ & $\begin{array}{c}\text { N. ret. of } \\
\text { yield } \\
\text { (L.E /fed)* }\end{array}$ & $\begin{array}{c}\text { Cost of W.C.T. } \\
\text { (L.E /fed) }\end{array}$ & $\begin{array}{l}\text { T. root } \\
\text { yield } \\
\text { ton/fed. }\end{array}$ & $\begin{array}{c}\text { N. ret. of } \\
\text { yield } \\
\text { (L.E /fed)* }\end{array}$ \\
\hline Glyphosate ( $36.0 \mathrm{~g}$ a.i./fed) & 120 & 11.86 & 10554 & 120 & 10.83 & 9627 \\
\hline Imazapic (20.0 g a.i./fed) & 140 & 12.02 & 10678 & 140 & 11.06 & 9814 \\
\hline Hand pulling twice & 400 & 9.31 & 7979 & 400 & 9.59 & 8231 \\
\hline Untreated check & 0 & 6.50 & 5850 & 0 & 5.97 & 5373 \\
\hline LSD : at $5 \%$ level & & 2.21 & & & 2.66 & \\
\hline
\end{tabular}

$* N$. ret $=$ Net return

Notice: The labor costs was assumed as 25

L.E/person per day

\section{Part II - Effect of weed control treatments on weeds and carrot:}

\section{A - On annual weeds:}

\section{- Susceptibility of weeds:}

Data in Table (5) illustrated that the susceptibility of weeds species was measured depending on the reduction of the dry weight of every species than untreated control after applied the soil-herbicides with 30 days interval. (Medicago interterta), Sonchus oleraceas and (Chenopodium spp.) as annual broad-leaved weeds were susceptible (> 90\%) to butralin at $96 \mathrm{~g}$ a.i. /fed, oxyfluronfen at $120 \mathrm{~g}$ ai/fed, metribuzin at $40 \mathrm{~g}$ a.i./fed and pendimethalin at $850 \mathrm{~g}$ a.i. /fed. Meanwhile, (Portulaca oleracea), (Beta vulgaris), (Ammi majus) and (Mililotus indicus) as annual broadleaved weeds and (Phalaris spp.) as annual grassy weed were moderately susceptible $(80-89 \%)$ to oxyfluronfen at $120 \mathrm{~g}$ a.i./fed., and metribuzin at $36 \mathrm{~g}$ a.i./fed. Further, (Portulaca oleracea) and (Phalaris spp.), were susceptible (> 90\%) to oxyfluronfen at $120 \mathrm{~g}$ a.i./fed, and pendimethalin at $850 \mathrm{~g}$ a.i./fed. (Beta vulgaris), (Ammi majus) and (Mililotus indicus) were fluctuated between susceptible and moderate susceptible to oxyfluronfen at $120 \mathrm{~g}$ a.i./fed, and pendimethalin at $850 \mathrm{~g}$ a.i./fed. These results obtained in the first season are confirmed with similar results in second season, that 
mean the previous four soil-herbicides therefore exceeded in a great extent to unweeded treatment from view point of controlling (Medicago interterta), (Sonchus oleraceas) and (Chenopodium spp.), (Portulaca oleracea), (Beta vulgaris), (Ammi majus) and (Mililotus indicus) as annual broad-leaved weeds and (Phalaris spp.) as annual grassy weeds.

Table 5. Susceptibility of annual weed species to some herbicides treatments at 30 days from application during 2011/12 and 2012/13 winter seasons.

\begin{tabular}{|c|c|c|c|c|c|c|c|c|}
\hline \multirow{3}{*}{ Weed control treatments } & \multicolumn{7}{|c|}{ 2011/12 season } & \multirow{3}{*}{$\begin{array}{c}\text { Annual } \\
\text { grassy } \\
\text { weeds } \\
\left(\mathrm{g} / \mathrm{m}^{2}\right) \\
\text { Phalaris } \\
\text { spp }\end{array}$} \\
\hline & \multicolumn{7}{|c|}{ Annual broad-leaved weeds $\left(\mathrm{g} / \mathrm{m}^{2}\right)$} & \\
\hline & $\begin{array}{l}\text { Medicago } \\
\text { interterta }\end{array}$ & $\begin{array}{l}\text { Sonchus } \\
\text { oleraceus }\end{array}$ & $\begin{array}{l}\text { Chenop } \\
\text { odium }\end{array}$ & $\begin{array}{l}\text { Portulaca } \\
\text { olevacea }\end{array}$ & $\begin{array}{l}\text { Beta } \\
\text { vularis }\end{array}$ & $\begin{array}{l}\text { Ammi } \\
\text { majus }\end{array}$ & $\begin{array}{c}\text { Melilotus } \\
\text { indicus }\end{array}$ & \\
\hline \multirow[t]{2}{*}{ Butralin (96.0 g a.i../fed) } & $(18.6)$ & $(11.4)$ & $(17.3)$ & $(32.4)$ & $(37.4)$ & $(35.2)$ & $(42.6)$ & (34.6) \\
\hline & $94 \mathrm{~S}$ & $96 \mathrm{~S}$ & $90 \mathrm{~S}$ & $87 \mathrm{MS}$ & $87 \mathrm{MS}$ & $86 \mathrm{MS}$ & 87 MS & $89 \mathrm{MS}$ \\
\hline \multirow[t]{2}{*}{ Oxyfluorfen (120.0 g a.i./fed) } & $(12.2)$ & $(10.2)$ & $(12.3)$ & $(25.7)$ & $(17.6)$ & $(42.6)$ & $(47.2)$ & $(26.2)$ \\
\hline & $97 \mathrm{~S}$ & $97 \mathrm{~S}$ & $96 \mathrm{~S}$ & $91 \mathrm{~S}$ & $91 \mathrm{~s}$ & $81 \mathrm{MS}$ & 86 MS & $91 \mathrm{~S}$ \\
\hline \multirow[t]{2}{*}{ Metribuzin (36.0 g a.i./fed) } & $(12.4)$ & $(19.3)$ & $(26.6)$ & $(28.5)$ & $(33.2)$ & $(41.8)$ & (32.4) & $(30.70$ \\
\hline & $97 \mathrm{~S}$ & $95 \mathrm{~S}$ & $91 \mathrm{~S}$ & 89 MS & 89 MS & $81 \mathrm{MS}$ & 89 MS & $88 \mathrm{MS}$ \\
\hline \multirow[t]{3}{*}{ Pendimethalin (850.0 g a.i./fed) } & (26.5) & (21.7) & $(11.6)$ & $(24.7)$ & (31.7) & (28.7) & $(46.9)$ & (27.1) \\
\hline & $92 \mathrm{~S}$ & $94 \mathrm{~S}$ & $96 \mathrm{~S}$ & $91 \mathrm{~S}$ & $88 \mathrm{MS}$ & $91 \mathrm{~S}$ & $86 \mathrm{MS}$ & $91 \mathrm{~S}$ \\
\hline & \multicolumn{8}{|c|}{$2012 / 13$ season } \\
\hline \multirow[t]{2}{*}{ Butralin (96.0 g a.i./fed) } & $(18.1)$ & $(27.3)$ & $(21.2)$ & $(31.6)$ & (37.4) & $(36.4)$ & $(41.5)$ & $(41.3)$ \\
\hline & $94 \mathrm{~S}$ & $84 \mathrm{MS}$ & $95 \mathrm{~S}$ & $89 \mathrm{MS}$ & 89 MS & $88 \mathrm{MS}$ & $88 \mathrm{MS}$ & $81 \mathrm{MS}$ \\
\hline \multirow[t]{2}{*}{ Oxyfluorfen (120.0 g a.i./fed) } & (12.5) & $(21.5)$ & (21.4) & $(21.6)$ & $(16.2)$ & $(38.3)$ & $(46.1)$ & $(24.2)$ \\
\hline & $97 \mathrm{~S}$ & $93 \mathrm{~S}$ & $95 \mathrm{~S}$ & $97 \mathrm{~S}$ & $90 \mathrm{~S}$ & $84 \mathrm{MS}$ & $86 \mathrm{MS}$ & $93 \mathrm{~S}$ \\
\hline \multirow[t]{2}{*}{ Metribuzin (36.0 g a.i./fed) } & (16.3) & $(25.3)$ & $(18.3)$ & (29.4) & $(42.6)$ & $(34.0)$ & $(31.0)$ & $(28.4)$ \\
\hline & $95 \mathrm{~S}$ & $89 \mathrm{MS}$ & $96 \mathrm{~S}$ & $87 \mathrm{MS}$ & 83 MS & $89 \mathrm{MS}$ & $88 \mathrm{MS}$ & 89 MS \\
\hline \multirow[t]{2}{*}{ Pendimethalin (850.0 g a.i./fed) } & (23.6) & $(23.4)$ & $(17.9)$ & $(26.2)$ & $(43.3)$ & (31.9) & $(43.2)$ & $(25.7)$ \\
\hline & $91 \mathrm{~S}$ & $92 \mathrm{~S}$ & $96 \mathrm{~S}$ & $93 \mathrm{~S}$ & $83 \mathrm{MS}$ & $92 \mathrm{~S}$ & $84 \mathrm{MS}$ & $92 \mathrm{~S}$ \\
\hline
\end{tabular}

\section{- Dry of broad-leaved weeds:}

Data in Table (6) indicated that dry weight of broad-leaved weeds $(\mathrm{g} / \mathrm{m} 2)$ was significantly influenced by weed control treatments. These findings were true at 
the two evaluated samples and such effect was constant from one season to another. The tested herbicides (butralin, oxyfluorfen, metribuzin, pendemrthalin) were effective in reducing the dry weight of broad-leaved and grassy weeds under natural heavy weed infestation, followed by hand weeding twice in the first and second seasons. These results are similar to these obtained by Sanjeev et al (2003) who found that the highest weed control efficiency were recorded from oxyfluorfen at $0.16 \mathrm{~kg}$ a.i./ha, pendimethalin at $0.75 \mathrm{~kg}$ a.i./ha and metribuzin at $0.70 \mathrm{~kg}$ a.i./ha, as compared to untreated check. The most effective treatments in reducing the dry weight of broadleaved weeds up to 75 days after sowing were oxyfluorfon $(90.0 \%)$, pendimethalin $(88.3 \%)$, metribuzin $(85.7 \%)$ and butralin $(84.4 \%)$ in the first season, while in the second season, they were 88.0, 86.2, 85.1 and $84.2 \%$, respectively. Hand weeding twice reduced the dry weight of broad-leaved weeds by 84.0 and $84,1 \%$, relative to the control at both growing seasons, respectively.

\section{- Dry weight of grassy weeds:}

Data presented in Table (6) indicated that weed control treatments had a significant effect on dry weight of grassy weeds. These results were fairly true after 45 and 75 days from sowing and this effect was constant from season to another. It could be noticed that dry weight of grassy weeds reached to about $\left(207.6 \mathrm{~g} / \mathrm{m}^{2}\right)$ in control plots at 75 days after sowing in the first seasons. All weed control treatments where significantly superior over the control plots. In this respect, the application of butratin, oxyfluorfen, metribuzin and pendimethalin gave about 86.8, 91.0, 89.1 and $90.5 \%$ reduction in dry weight of grassy weeds in the first season, respectively compared with the untreated check. The results of those treatments in the second season gave the same trend. These results were in harmony with those reported by Hegazy et. al. (1993), who revealed that using oxyfluorfen as post-emergence resulted in a good control of annual weeds.

\section{- Dry weight of total weeds:}

Data in Table (6) also revealed that dry weight of total weeds $/ \mathrm{m}^{2}$ was significantly affected by weed control treatments. However, it could be noticed that all herbicides were highly effective for reducing the dry weight of total weeds than that of untreated check. These findings were true after 45 and 75 days from sowing and this effect was constant from season to another. This means that applying was necessary to eliminate the weed plants that survived or escaped from the herbicides. Similar results were obtained by Hegazy et. al. (1993) and Sanjeev et al (2003). 
Table 6. Effect of weed control treatments on dry weight of annual weeds $\left(\mathrm{g} / \mathrm{m}^{2}\right)$ after 45 and 75 days from sowing in 2011/12 and 2012/13 winter seasons.

\begin{tabular}{|c|c|c|c|c|c|c|}
\hline \multirow{3}{*}{ Weed control treatments } & \multicolumn{6}{|c|}{ 2011/12 season } \\
\hline & \multicolumn{3}{|c|}{$\begin{array}{l}\text { Dry weight of weeds in } \mathrm{g} / \mathrm{m}^{2} \text { at } 45 \\
\text { days from sowing }\end{array}$} & \multicolumn{3}{|c|}{$\begin{array}{c}\text { Dry weight of weeds in } \mathrm{g} / \mathrm{m}^{2} 75 \text { days } \\
\text { from sowing }\end{array}$} \\
\hline & $\begin{array}{l}\text { Broad-leaved } \\
\text { weeds }\left(\mathrm{g} / \mathrm{m}^{2}\right)\end{array}$ & $\begin{array}{l}\text { Grassy } \\
\text { weeds } \\
\left(\mathrm{g} / \mathrm{m}^{2}\right)\end{array}$ & $\begin{array}{c}\text { Total } \\
\text { weeds } \\
\left(\mathrm{g} / \mathrm{m}^{2}\right)\end{array}$ & $\begin{array}{l}\text { Broad-leaved } \\
\text { weeds } \\
\left(\mathrm{g} / \mathrm{m}^{2}\right)\end{array}$ & $\begin{array}{l}\text { Grassy } \\
\text { weeds } \\
\left(\mathrm{g} / \mathrm{m}^{2}\right)\end{array}$ & $\begin{array}{c}\text { Total } \\
\text { weeds } \\
\left(\mathrm{g} / \mathrm{m}^{2}\right)\end{array}$ \\
\hline Butralin (96.0 g a.i./fed) & 80.8 & 17.8 & 98.6 & 306.9 & 28.4 & 335.3 \\
\hline Oxyfluorfen (120.0 g a.i./fed) & 57.6 & 13.9 & 71.5 & 196.4 & 15.8 & 212.2 \\
\hline Metribuzin (36.0 g a.i./fed)) & 75.6 & 16.4 & 92.0 & 280.4 & 16.7 & 297.1 \\
\hline Pendimethalin $\quad(850.0 \quad \mathrm{~g}$ & 65.3 & 14.8 & 80.1 & 229.3 & 16.4 & 245.7 \\
\hline a.i./fed) & 83.7 & 18.6 & 102.3 & 314.9 & 31.4 & 346.3 \\
\hline $\begin{array}{l}\text { Hand weeding twice } \\
\text { Untreated check }\end{array}$ & 319.8 & 98.0 & 417.8 & 1964 & 207.6 & 2151 \\
\hline \multirow[t]{2}{*}{ LSD at $5 \%$} & 72.4 & 42.6 & 83.7 & 265.2 & 68.8 & 112.4 \\
\hline & \multicolumn{6}{|c|}{ 2012/13 season } \\
\hline Butralin (96.0 g a.i./fed) & 85.4 & 19.4 & 104.8 & 251.7 & 29.6 & 281.3 \\
\hline Oxyfluorfen (120.0 g a.i./fed) & 60.5 & 14.3 & 74.8 & 190.8 & 19.7 & 210.5 \\
\hline Metribuzin (36.0 g a.i./fed)) & 74.8 & 17.6 & 102.4 & 236.6 & 23.9 & 260.3 \\
\hline Pendimethalin $\quad(850.0$ & 80.3 & 16.8 & 97.1 & 219.6 & 20.8 & 230.4 \\
\hline a.i./fed) & 92.6 & 21.3 & 113.9 & 252.5 & 36.8 & 296.3 \\
\hline $\begin{array}{l}\text { Hand weeding twice } \\
\text { Untreated check }\end{array}$ & 412.0 & 80.7 & 402.7 & 1592 & 219.4 & 1811 \\
\hline LSD at $5 \%$ & 64.8 & 34.9 & 71.3 & 197.8 & 49.3 & 93.8 \\
\hline
\end{tabular}

\section{B - On carrot yield and its components:}

Data in Table (7) indicated that weed control treatments had a significant effect on root length at harvest during the two growing seasons. Hand weeding twice application gave the highest values and significantly increased the root length of carrot than the control at the harvest by (31.5 and $26.8 \%$ ) in both seasons, respectively.

Butralin, oxyfluorfen, metribuzin and pendimethalin were significantly superior over hand weeding twice. Also, oxyfluorfen, pendimethalin and metribuzin superior in the length of carrot plants and recorded the root length $(16.68,16.46$ and $15.70 \mathrm{~cm})$, respectively as compared to hand weeding twice treatment $(13.15 \mathrm{~cm})$ at harvest in first season, this effect was constant at the second seasons. This reduction in root length under the control plots might be attributed to the negative effects of weeds on crop growth which may be occurred as a result of the competition between carrot and weed plant. 
Table 7. Effect of weed control treatments on yield and its components at harvest in carrot during 2011/2012 and 2012/2013 winter seasons.

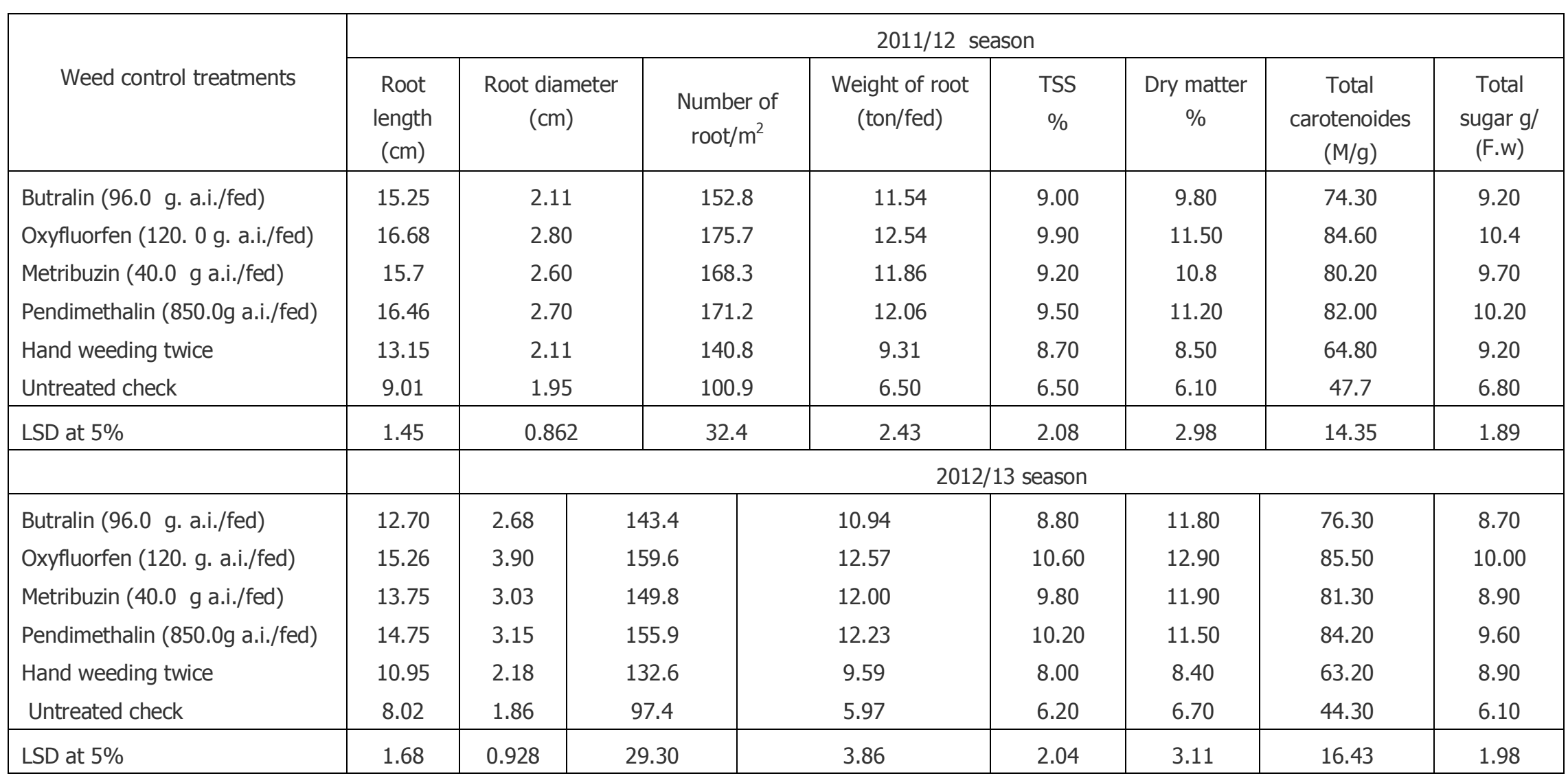


Data revealed that root diameter was significantly affected by weed control treatments at harvest during the two growing seasons. Plots that were hand weeding twice produced the thickest stem as compared to herbicide treatments. It could be noticed that the results of this character had the same trend of that of root length under this study.

This reduction in the untreated check reflect the negative impacts of weeds on crop growth which may be occurred as a result of the competition between carrot and weed plants for the environmental resources (light, water and nutrients) which are necessary for plant growth. Chemical weed control treatments were superior in increasing root diameter of carrot that hand weeding twice and control treatments, during both growing seasons. These results were in complete agreement with these obtained by Farag et. al. (1994).

Data in Table (7) further indicated that the number of carrot root $/ \mathrm{m}^{2}$ was significantly affected by weed untreated check during the two growing seasons. Results illustrated that weed control treatments were correlated with an increase in number of carrot $/ \mathrm{m}^{2}$ in both seasons. This might be due to the eliminating treatment exposed to competition of annual weeds. The highest significant number of carrot root $/ \mathrm{m}^{2}$ was obtained from oxyfluofen, pendimethalin, metribuzin, and butralin. These treatments increased the number of carrot root $/ \mathrm{m}^{2}$ by $(42.6,41.1,40.0$ and $33.9 \%$ ) in the first season, respectively. The results of these treatments in the second season gave the same trend. Meanwhile, the hand weeding treatment gave the lowest increase in number of carrot root $/ \mathrm{m}^{2}$ (28.3 and $26.5 \%$ ) in the both seasons, respectively, compared to the untreated check.

Data revealed that weed control treatments had a significant effect on final carrot root yield (ton/fed) in both growing seasons. Dense weeds growing with carrot plants all over the growing seasons in control plots resulted in the lowest yield ( 6.50 and 5.97 ton/fed). The significant increases in carrot yield and its components accompanied with the quality were obtained by all herbicides used and hand weeding treatment. Further, the herbicides while were more efficient in controlling broomrape or annual weeds caused the highest increases in quantity and quality of carrot. This was true in the both seasons.

Data showed that all tested herbicides were significantly superior over the treatments in carrot root yield/ fed in both seasons. In this respect, the highest carrot root yield/ fed (12.54 and 12.57 ton/fed) was achieved from oxyfluorfen, followed by pendimethalin ( 12.06 and 12.23 ton/fed), respectively in the both seasons. This may be due to that applying the herbicides were necessary to eliminate the weed plants, 
which survived or escaped from the herbicides and assure the importance of using the suitable herbicides due to the expected problem of weed flora.

Results presented in Table (7) showed the effect of weed control treatments had a significant effect on total soluble solids in carrot root and all exceeded significantly untreated check in both seasons. Oxyfluorfen, pendimethalin, metribuzin and butralin treatments were the potent treatments. These results are similar to those reported by Farag et. al. (1994).

All herbicidal treatments (oxyfluorfen, pendimethalin, metribuzin and butralin) were exceeded in dry matter in carrot content roots in the two seasons, compared to the untreated check. Meanwhile, the hand weeding treatment gave the lowest increase in dry matter in carrot roots (28.2 and $20.2 \%$ ) in both seasons, respectively, compared to the untreated check.

Data in Table (7) also, revealed that all herbicides treatments gave higher total carotene content in both seasons and were not significantly different in most cases. On the other hand, the untreated check was the lowest in total carotene content. The reduction in carotene content values, under hand weeding and untreated check treatments, reflected the negative impacts of annual weeds on carrot growth, which might occur as a result of competition between carrot and weeds. Also, the results showed that, using the tested herbicides was necessary to eliminate weeds and to avoid its negative impacts on carrot. Similar results had been reported by Farag et. al. (1994).

Regarding the effect of weed control treatments on total sugars in carrot roots, data indicated that all tested herbicides gave the highest total sugars in carrot roots. Hand weeding gave the lowest total sugars, compared to all tested herbicides. This result showed that a single hand weeding was insufficient to provide the desired weed control level and this was reflected on the limited increases in carrot growth. Such results, presented in Table (6) agreed with those obtained by Farag et. al. (1994). These effects might be attributed to the dominant weeds in the hand weeding treatment, and this assured the importance of using suitable herbicides.

\section{-Economic analysis.}

Data in Table (8) showed that the net profit of carrot roots yield by weed control treatments in the first season could be arranged in a descending order as follows: 11026 LE by oxyfluronfen at $120 \mathrm{~g}$ a.i./fed, 10554 LE by pendimethalin at 850 $\mathrm{g}$ a.i. /fed, $10466 \mathrm{LE}$ by metribuzin at $40 \mathrm{~g}$ a.i./fed, (10116 LE) by butralin at $96 \mathrm{~g}$ a.i. /fed. and ( 8748 LE) by hand weeding twice, compared to untreated check (6570 LE). In second season the same trend approximately for net profit was confirmed to those observed in the first season. The net benefit of carrot roots yield by the following 
treatments in a descending order was 11053 LE by oxyfluronfen at $120 \mathrm{~g}$ a.i./fed., (10807 LE) by pendimethalin at $850 \mathrm{~g}$ a.i. /fed, (10610 LE) by metribuzin at $40 \mathrm{~g}$ a.i./fed, (9198 LE) by hand weeding twice and (9576 LE) by butralin at $96 \mathrm{~g}$ a.i. /fed. compared to untreated check (6156 LE). These results are agreement with those reported by (Sanjeev et. al. 2003,) who found that use of the herbicide pendimethalin and hand hoeing gave the highest yield and net return.

Table 8. Cost of weed control treatments, total root yield ( $t / f e d)$ and net return of carrot yield (L.E./fed.) as affected by weed control treatments during 2011/12and 2012/13 seasons.

\begin{tabular}{|c|c|c|c|c|c|c|}
\hline \multirow[b]{2}{*}{ Weed control treatments } & \multicolumn{3}{|c|}{$2011 / 12$} & \multicolumn{3}{|c|}{$2012 / 13$} \\
\hline & $\begin{array}{l}\text { Cost of } \\
\text { W.C.T. } \\
\text { (L.E /fed) }\end{array}$ & $\begin{array}{l}\text { T. root } \\
\text { yield } \\
\text { (ton/fed.) }\end{array}$ & $\begin{array}{c}\text { N. ret. of } \\
\text { yield } \\
\text { (L.E /fed)* }\end{array}$ & $\begin{array}{l}\text { Cost of } \\
\text { W.C.T. } \\
\text { (L.E /fed) }\end{array}$ & $\begin{array}{c}\text { T. root } \\
\text { yield } \\
\text { (ton/fed.) }\end{array}$ & $\begin{array}{c}\text { N. ret. of } \\
\text { yield } \\
\text { (L.E /fed)* }\end{array}$ \\
\hline Butralin (96.0 g, a.i./fed) & 270 & 11.54 & 10116 & 270 & 10.94 & 9576 \\
\hline Oxyfluorfen (120.0 g, a.i./fed) & 260 & 12.54 & 11026 & 260 & 12.57 & 11053 \\
\hline Metribuzin $(40.0 \mathrm{~g}$, a.i./fed) & 190 & 11.84 & 10466 & 190 & 12.00 & 10610 \\
\hline Pendimethalin (850.0 g, a.i./fed) & 300 & 12.06 & 10554 & 300 & 12.23 & 10807 \\
\hline Hand weeding twice & 450 & 10.22 & 8748 & 450 & 10.72 & 9198 \\
\hline Untreated check & 0 & 7.30 & 6570 & 0 & 6.84 & 6156 \\
\hline LSD : at $5 \%$ level & & 2.43 & & & 3.86 & \\
\hline
\end{tabular}

$* N$. ret $=$ Net return

Notice: The labor costs was assumed as 25 L.E/person per day

\section{REFERENCES}

1. Aviv, D., Z. Amsellem and J. Gessel. 2002. Transformation of carrots with mutant acetoloctate synthase for Orobanche (broomrape) control. Pest Management Sci., $58: 12,1187-1193$.

2. Boydston, Rich, W. Martin, P. G. Prosser and S. Dollars. 2003. Carrot weed control - Research with caparol and notron Proceedings of the Pacific northwest vegetable association, PASCO, P. 81-88. 
3. Carl, E., B. Brent, E. B Outwell, E. J. Ogbuchickwe, E. Milt and J. Mcgiffen. 2000. Weed control in carrots the efficacay and economic value of linuron. Hort Sci. 35 (6):1089- 1091.

4. Dillard, H. R., R. R. Bellinder and D. A. Shah. 2004. Integrated management of weeds and dieases in a cabbage cropping system. Crop-protection. 23(2): 163168.

5. Dittmar, P.J. and W. M. Stall. 2012. Weed control in carrot. This document is HS201, one of

6. a series of the Horticultural Sciences Department, Florida Cooperative Extension vice, Institute of Food and Agricultural Sciences, University of Florida.

7. Dixit, A. J. , J. R. Ramteke, S. T. Thorate and N. D. Jambhale. 2005. Efficacy of herbicides in controlling weeds in cabbage. Maharashtra J.Agric. Univ. 30 (3): 362-363.

8. Farag, I. A., H. A. Hussein and M. A. Farghali. 1994. Effect of chemical weed control on growth of weeds, yield and quality of carrot. Assiut J. of Agric. Sci., 25: 3, 1-12.

9. Frans, R.E. and R. Talbet. 1977. Design of field experminent and the measurement and analysis of plant response. Res. Methods in Weed Sci. Soc. Field. South. USA, Aburn, Alabama.

10. Ghalwash, A. M., I. E. Soliman and Azza E. Khaffagy. 2008. Performance of some faba bean (Vicia faba, L.) cultivars under numerous broomrape (Orobanche crenata, Forsk.) control treatments. J. Agric. Sci. Mansoura Univ., 33 (4): 24392448.

11. Hegazy,R. T., H. M. El-Sheakh and A. K. I. Kafoury. 1993. Effect of planting methods and some herbicides on the growth of onion seedlings and weeds in nursery. Egypt. J. Appl. Sci., 8 (9): $388-397$.

12. Hassanein, E. E. and A. S. Kholosy. 1997. Demonstration plots of faba bean for broomrape control in fayoum Governorate. NVRP for wild oats control in wheat and other winter crops. 5th Annual Meeting, Cairo, 11-15 Sept: 109-111.

13. Jacobsohn, R. and Y.Kelman. 1982. Proper timing of glyphoste application for broomrape control in carrot and celery. Phytoparasitica, 10: (4), 268.

14. Jacobsohn, R. Geenberger, A. , Katan, J., Levi, M. and H. Alon. 1980. Control of Egyptain broomrape (Orobanche aegyptica ) and other weeds by means of solar heating of the soil by ployethlene mulching. Weed Sci. 28 (3): 312- 316.

15. Karaliauskaite,D., Starkute, R., Bundiniene O., J. Jankauskiene. 2008. Chemical weed control in carrot crop ISHA Acta Horticulturae 830: iv Balkan Symposium on vegetable and potatoes. 
16. Nandula, V. K., J. G.Foster and C. L. Fay. 2002. Impact of Egyptian broomrape (Orobanche aegyptica, Pers) parasitism on amino acid composition of carrot (Daucus carota,L.) . J. of Agric., and Food Chemistry, 48 (9): 3930-3934.

17. Poschenok, N. 1976. Biochemical analytical methods of plants. Publishers, Naokova Damka Kiev, 276 PP. (In Russian).

18. Ranganna, S. 1977. Mannual of analysis of fruit and vegetable products. Tata Mcgraw - Hill Publishong company Limited, New Delhi, PP. 634.

19. Sanjeev, A., K. S. Sandhu and S. Ahuja. 2003. Efficiency of weed control in cabbage onion cropping system. Annual of Biology. 19 (1) : 31- 34.

20. Schaffer, A.A., R. Jacobsohn, D. M. Joel, E. Eliassi and M. Fogelman. 1991. Effect of broomrape (Orobanche spp.) infection on sugar content of carrot roots. Hort. Sci., 26 (7): 892- 903.

21. Snedecor, G. W. and W. G. Cachran. 1980. " Statistical Methods "6 th ed., Iowa State Univ. Press, Ames. Igrawowa, U.S.A, 325-330.

22. Topps, J. H. and R.L. Wain. 1957. Investigation of fungi toxicity of 3- and 5-alkyl salicylinlide and para- chloroaniline. Ann. Appli. Biol. 45 (3): 506-511. 


\section{مكافحة الهالوك و الحشائش الأخري فى الجزر}

عادل مصطفى غلوش * إبر اهيم السيد سليمان * وعزة السيا خفاجى *

$$
\text { المعمل المركزى لبحوث الحشائش - مركز البحوث الزراعية - الجيزة - مصر }
$$

اجريت أربعة تجارب حقلية فى المزرعة البحثية بمحطة البحوث الزر اعية بسخا محافظة

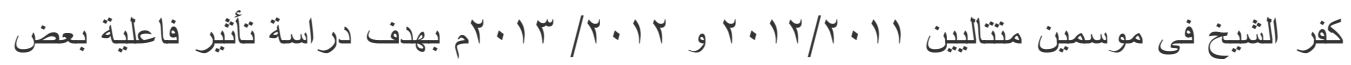
معاملات مكافحة الحشائش على حثيشة الهالوك و الحشائش الحولية و انعكاس ذلك على محصول

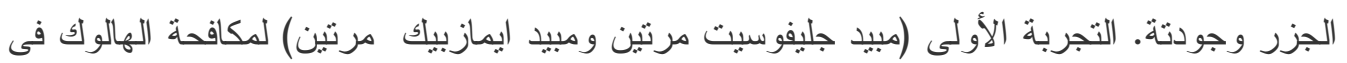
محصول الجزر بينما شملت التجربة الثانية استخدم مبيد بنديمثالين و البيوتز الين و الاكسيفلورفين و المتربيوزين بعد انبات نباتات الجزر) لمكافحة بعض الحشائش الحولية فى محصول الجزر بالاضافة الى النقاوة اليدوية مرتين ـ مقد أثنارت النتائج المتحصل عليها التجربة الاولى أعطى مبيد

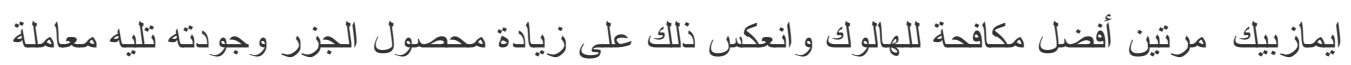
النقاوة اليدوية مرتين و مبيد جليفوسيت مرتين على الترنيب. وقد أكدت هذه النتائج تحت العدوى

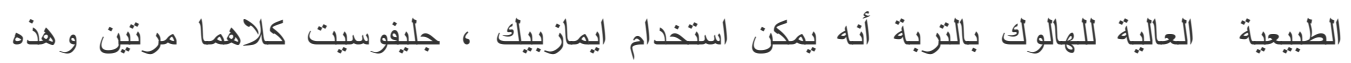

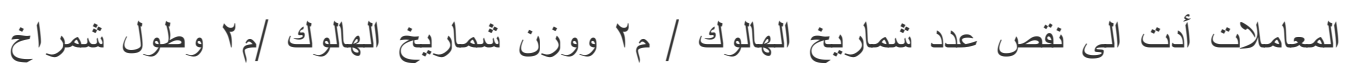

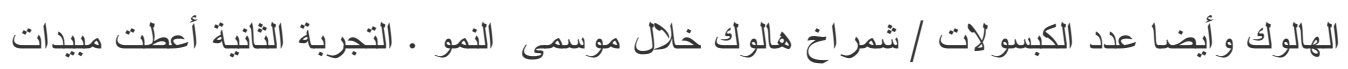

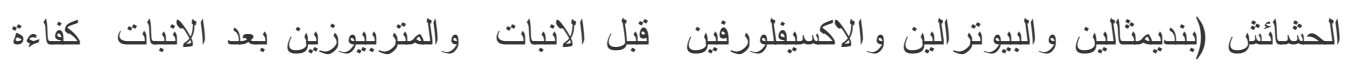
عالية ضد الحشائش العريضة و النجيلية ـ أدى استخدام مبيدات الحشائش الى نقص كبير فئر فئ الوزئن الجاف للحشائش عريضة الأوراق وضيقة الأوراق والحشائش الكلية حيث ظهر ذلك من استخدام مبيدات الحشائش ( اكسيفلورفين ، بنديمثالين، متربيوزين و بيونز الين و النقاوة اليدوية مرتين) في كلا

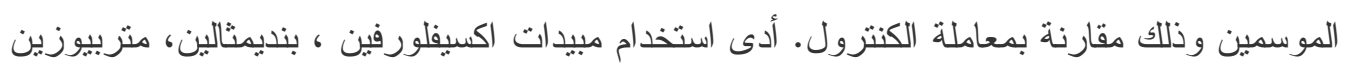

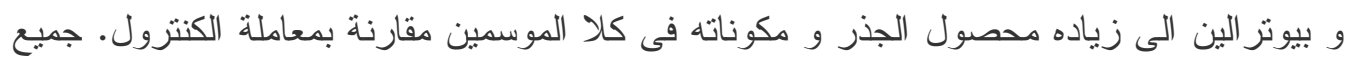
مبيدات الحشائش السابقة أعطت زيادة معنوية لصفات الجودة في الجزر لبئ بينما معاملة النقاوة البدوية

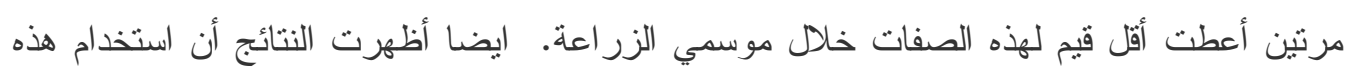

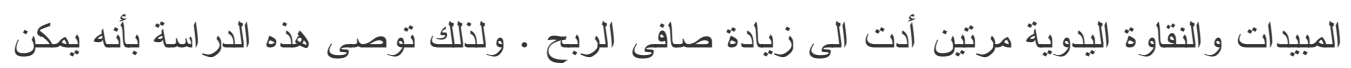

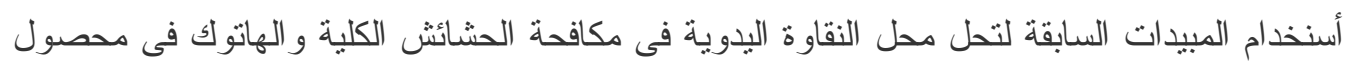

